\title{
Arbeidslivsregimer i Danmark og Norge - går de hver sin vei?
}

Navrbjerg, Steen Erik; Gooderham, Paul; Olsen, Karen M. ; Steen, Christina R.

Published in:

Tidsskrift for Arbejdsliv

Publication date:

2011

Document version

Også kaldet Forlagets PDF

Citation for published version (APA):

Navrbjerg, S. E., Gooderham, P., Olsen, K. M., \& Steen, C. R. (2011). Arbeidslivsregimer i Danmark og Norge går de hver sin vei? Tidsskrift for Arbejdsliv, 13(3), 30-44. http://www.nyt-om-

arbejdsliv.dk/images/pdf/2011/nr3/tfa3_2011_030_044.pdf 


\title{
Arbeidslivsregimer i Danmark og Norge - går de hver sin vei?
}

\author{
Paul Gooderham, Steen E. Navrbjerg, Karen M. Olsen \& Christina Roe Steen
}

Generelt vurderes det norske og det danske arbeidslivregimet som bortimot identiske: Begge er koordinerte markedsøkonomier der arbeidsmarkedet i stor grad reguleres gjennom partsavtaler. Men spørsmålet er om de to regimene er i ferd med å gå i ulike retninger, og i så fall $\mathrm{i}$ hvilken grad dette er en følge av utviklingen av flexicurity i dansk arbeidsliv. Med utgangspunkt $i$ analyser av de norske og danske institusjoner og av multinasjonale selskapers tilgang til de to arbeidsmarkedsmodellers institusjoner (særlig fagforeninger og samarbeidssystemer) belyses forskjeller mellom den danske og den norske arbeidsmarkedsmodellen. Ny-institusjonell teori, herunder Varieties of Capitalism, brukes som teoretisk utgangspunkt.

$\mathrm{N}$ y institusjonell teori er etablert som en sentral tilnærming i analyser av forskjeller mellom arbeidslivsregimer i ulike land. Blant annet ved å fremheve betydningen av formelle regulatoriske ulikheter mellom land, har ny institusjonell teori kastet lys over vesentlige forskjeller i bruk av ulike HRM praksiser land i mellom. Selv om det finnes ulike varianter av ny institusjonell teori (DiMaggio \& Powell 1991; Scott 2001; Tolbert \& Zucker 1996), er et fellestrekk at organisasjoner står under et press til å tilpasse seg sine omgivelser på en slik måte at deres organisasjonsformer oppfattes som legitime (Meyer \& Rowan 1977). Mister de denne legitimiteten står de $\mathrm{i}$ fare for å bli eksponert for sanksjoner fra omgivelsene. Presset kan operere på tre distinkte, men overlappende nivåer: det kognitive, det normative eller det legale. I denne artikkelen vil vi ha et særlig fokus på det legale - eller i en nordisk sammenheng med en sterk tradisjon for regulering via overenskomster - det regulatoriske presset på firmaer.
På bedriftsplan innebærer det regulatoriske presset at bedrifters valg av organisasjonsformer ikke bare er relativt begrenset, men også relativt stabile. I den grad det forekommer endringer i de institusjonelle omgivelsene er dette 'path dependent' (cf. Hollingsworth 2006), noe som innebærer stor grad av kontinuitet i organisasjonsformer. Denne kontinuiteten kommer tydelig frem i kryssnasjonale undersøkelser av endringer over tid i arbeidslivsrelasjoner (Katz \& Darbishire 2000) og i HRM-praksiser (Gooderham \& Nordhaug 2011). I denne artikkelen er det imidlertid et vesentlig poeng at 'flexicurity' modellen i Danmark utgjør en viktig regulatorisk forskjell mellom Danmark og de andre nordiske landene (Madsen et al. 2011). En større nordisk studie konkluderer:

"The main conclusion of this study is that Denmark has a special combination of institutions related to its labour market. And this flexicurity nexus leads to higher mobility rates on the labourmarket." (TemaNord 2010, 13). 
På grunn av at arbeidsgivere i Danmark har større frihet enn i Norge med hensyn til enkelte bemanningsløsninger kan dette påvirke måten virksomheter organiserer arbeid og inkluderer fagforeninger i spørsmål knyttet til bemanning. Vi utforsker i hvilken grad dette kommer til syne i forskjeller mellom arbeidslivsregimene i Norge og Danmark.

\section{Regimer og institusjonelle forskjeller}

\section{Norge og Danmark som Coordinated Market Economies}

I en analyse av avanserte økonomier skiller Hall og Soskice (2001) mellom to generiske institusjonelle kontekster, LME (liberal market economies) og CME (coordinated market economies). Typiske LME regimer er de anglosaksiske landene som USA og Storbritannia, mens typiske CMEs er nordvesteuropeiske land som Tyskland, Norge og Danmark. I LMEs koordineres samhandlingen mellom firmaer og andre aktører som for eksempel fagforeninger og banker på grunnlag av frie markeder. I CMEs derimot er denne samhandlingen til dels løftet ut av markedet slik at samhandlingen foregår mellom 'stakeholders' og på et mer strategisk eller langsiktig grunnlag. Her er for eksempel et samspill mellom det politiske systemet og arbeidsmarkedets parter om reguleringen av arbeidsmarkedsforhold. En vesentlig del av arbeidsmarkedet er regulert via kollektive overenskomster i samspill med lovgivning. Når det konkret gjelder relasjonen mellom firmaledelsen og fagforeninger innebærer dette at i CME-baserte firmaer er det en betydelig større grad av konsulering i forbindelse med strategiske valg - som for eksempel outsourcing og nedbemanning - enn man finner i LMEbaserte firmaer. I forhold til HRM praksiser forbindes LME-CME skillet med en rekke forskjeller: lønnsforskjeller i LME-firmaer er betydelig større og lønnforhandlinger mere individualiserte enn i CME-firmaer; og oppsigelsesvern er vesentlig svakere i LME-firmaer enn i CME-firmaer.

Dette LME-CME skillet har fått et klart empirisk uttrykk i en indeks som Hall og Gingerich (2004) har utviklet der USA og Tyskland er motpoler. Indeksen avdekker imidlertid at mens Norge og Danmark utvilsomt er CME-land, er de også noe forskjellige fra Tyskland. Mens Tyskland er et fullkomment CME, er det en rekke land som for eksempel Norge og Danmark som har en noe mer tvetydig plassering innenfor CME-kategorien (Campbell et al. 2006). En betydningsfull forskjell man kan observere mellom nordiske land og Tyskland er graden av formaliseringen av det regulatoriske. I nordiske land er lovgivningen som styrer relasjonen mellom arbeidsgiver og arbeidstakerorganisasjoner mer fleksibel i sin utforming og praktisering, og på mange områder reguleres arbeidsmarkedet i høyere grad av overenskomster enn via lovgivning. Dermed er det blitt vanlig å omtale en egen nordisk modell (Løken 2009).

I forhold til Danmark har Madsen, Due og Andersen $(2011,225)$ påpekt at selv om Danmark er

"a typical coordinated market economy... Danish labour market regulation also encompasses clear liberal elements...with the greater part of its regulation taking place within the framework of collective bargaining and not via legislation."

Dette står i kontrast med Tyskland der "(the) extensive social regulation...has always been regulated by law and not by collective bargaining" (Keller \& Kirsch 2011, 197). Det er ikke minst dette skillet som gjør det rimelig å fremheve den nordiske modellen som dis- 
tinkt fra den tyske. Ved en mer finkornet inndeling i ulike regimer har man også funnet at Danmark og Norge havner i ulike klynger av land, blant annet på grunn av forskjeller i oppsigelsesvern og at enkelte relasjoner mellom arbeidstakere og -givere er mindre preget av motstand i Norge (Amable 2003). Videre har man påpekt at HRM i Danmark er mindre formalisert, strukturert og topp-tungt enn i Norge (Rogaczewska et al. 2004). Forøvrig finnes mange likhetstrekk mellom arbeidsmarkedene i Danmark og Norge, med for eksempel høyt utviklete kunnskaps- og servicebaserte økonomier (Rogaczewska et al. 2004).

Med utgangspunkt i skillet mellom den legalistiske konteksten til Tyskland og den mer fleksible nordiske konteksten viser Gooderham, Nordhaug og Ringdal (1999) at dette resulterer i to ulike HRM regimer. I motsetning til tysk arbeidsliv er det nordiske kjennetegnet av et betydelig innslag av konsulterende HRM praksiser der en betydelig del av dialogen mellom arbeidsgiver og ansatte foregår lokalt og uten formalisering. Når det er sagt har begge regimene det til felles at innslaget av kalkulative HRM praksiser er betydelig mindre enn i anglosaksiske land. For eksempel er bruken av individuell prestasjonslønn betydelig lavere i Tyskland og de nordiske landene enn i anglosaksiske land.

En kritikk som rettes mot den ny institusjonelle tilnærmingen og ikke minst 'varieties of capitalism' (VoC) tilnærmingen til Hall og Soskice er at den mangler aktør- og konfliktperspektiver og er derfor for deterministisk. Dette innbærer at endring vanskelig kan forklares innenfor et VoC-rammeverk. Som Wailes, Bamber og Lansbury $(2011,24)$ påpeker:

"While national employment relations patterns may not be converging towards a single neo-liberal model, there is overwhelming evidence that change is a common feature of employment relations in many countries."

En annen kritikk som rettes mot ny institusjonelle tilnærminger er at den overvurderer graden multinasjonale selskaper tilpasser seg. En rekke studier viser klare 'country-of-origin' effekter (Wailes et al. 2011). Gooderham, Nordhaug og Ringdal (2006) finner at disse er spesielt synlige $i$ den nordiske konteksten der den relativt liberale regulatoriske konteksten åpner for hybride løsninger. Med andre ord er datterselskaper til multinasjonale selskaper i nordiske land i betydelig grad preget av andre HRM tilnærminger enn de etablerte nordiske. Gitt den klare 'country-of-origin' effekten vil vi derfor som utgangspunkt ha den overordnede antakelse om at datterselskaper til multinasjonale selskaper ikke nødvendigvis vil ha en nordisk tilnærming til fagforeninger eller til HRM.

\section{'Flexicurity' og forskjeller mellom Danmark og Norge}

Et sentralt trekk ved 'flexicurity' modellen i Danmark er at den kombinerer elementer fra velferdssystemer og arbeidsmarkedsreguleringer (Anderson \& Pontusson 2007; Madsen 2003). Tanken er at dette skal fremme både fleksibilitet og trygghet på arbeidsmarkedet. Modellen kjennetegnes blant annet ved et relativt svakt oppsigelsesvern, en sjenerøs arbeidsledighetsforsikring og en aktiv arbeidsmarkedspolitikk (Madsen 2003; TemaNord 2010). Et svakt oppsigelsesvern gir arbeidsgivere en fleksibilitet i forhold til bemanningsløsninger. Dette omtales gjerne som en kilde til numerisk eller ekstern fleksibilitet (e.g. Pfeffer \& Baron 1988). Madsen, Due og Andersen $(2011,224)$ påpeker at denne ordningen har bidratt til å gi danske arbeidsgivere en grad av bemanningsfleksibilitet "on par with that of the United Kingdom" slik dette hen- 
seendet er Danmark "different from that of the other Nordic countries." Et spørsmål som oppstår er om denne forskjellen mellom Danmark og de andre nordiske landene etter hvert preger forholdet mellom danske arbeidsgivere og fagforeninger? Likedan: er det slik at HRM praksiser i danske bedrifter avviker fra de som anvendes i bedrifter i de øvrige nordiske landene?

'Flexicurity' modellen har utviklet seg i kryssfeltet mellom arbeidsgivernes etterspørsel etter økt rett til å bedrive desentraliserte forhandlinger med arbeidstakere og fagbevegelsens krav om fastholdelsen av de sterke kollektive avtalene. Dette står i motsetning til for eksempel Storbritannia, hvor desentraliseringen gikk hånd i hånd med en svekking av fagforeningene og det kollektive avtalesystemet.

$\mathrm{Vi}$ antar at to typer reguleringer er spesielt viktig for hvordan HRM praktiseres: (1) reguleringer som begrenser eller utvider arbeidsgivers bruk av ulike bemanningsløsninger og (2) opplysnings- og konsultasjonsplikt i forbindelse med endringer i bemanning og organisering av arbeid.

I forhold til spørsmål om bemanning er en spesielt viktig forskjell mellom de regulatoriske rammeverkene i Norge og Danmark oppsigelsesvernet. I en sammenlikning av 40 OECD-land er Danmark blant de 12 landene med minst strengt oppsigelsesvern (employment protection legislation $(E P L))$ mens Norge rangerer som det niende strengeste landet (OECD 2008) (Se også TemaNord (2010) for diskusjon av ulike mål for oppsigelsesvern.) EPL- indeksen bygger på reguleringer rundt midlertidig ansettelse og oppsigelse (individuelle oppsigelser og masseoppsigelser/nedbemanning). Norge har vesentlig strengere vern enn Danmark når det gjelder midlertidige ansettelse og individuelle oppsigelser. For kollektiv oppsigelse er det danske regelverk noe strengere enn det norske.
Andre reguleringer som er relevante for bemanning vil for eksempel være outsourcing og innleie av arbeidskraft. Adgang til å ta i bruk outsourcing, innleie av arbeidskraft og midlertidig ansettelser er regulert $\mathrm{i}$ Arbeidsmiljøloven i Norge. I tillegg er prosessene ved bruk og endringer i bemanning også nedfelt i tariffavtaler. Selve betegnelsen 'outsourcing' brukes ikke i det norske lovverket, men virksomhetsoverdragelse tolkes dit hen. Hovedregelen ved virksomhetsoverdragelse er at arbeidstakere overføres til det nye selskapet og beholder sine rettigheter og forpliktelser. Ved virksomhetsoverdragelse til et annet land vil man typisk avvike fra denne hovedregelen. Også restrukturering og endringer internt i organisering av arbeid, for eksempel endring av arbeidssted eller nye arbeidsoppgaver er regulert (Jusstorget 2011). Når det gjelder opplysning og konsultasjon har arbeidsgivere i Norge en rekke plikter i forhold til å opplyse og drøfte endringer som vedrører bemanning og endringer i organisering av arbeid. Slike plikter er nedfelt i arbeidsmiljøloven, tariffavtaler, samt sedvane. Ifølge arbeidsmiljøloven og tariffavtaler (for eksempel Hovedavtalen LO-NHO) må eventuelle nedbemanninger drøftes med tillitsvalgte så tidlig som mulig. De tillitsvalgte gis anledning til å uttale seg om grunnlaget for nedbemanningen og eventuelle kriterier som skal ligge til grunn. Gjennom styringsretten er det i siste instans arbeidsgiver som bestemmer og som står ansvarlig for eventuelle oppsigelser (Jusstorget 2011). Når det gjelder bruk av midlertidig ansatte er det fra 2010 et krav i henhold til Arbeidsmiljøloven, § 14-9, at arbeidsgiver må drøfte bruk av midlertidig ansettelse med tillitsvalgte minst en gang $\mathrm{i}$ året.

I Danmark er Samarbejdsaftalen fra 2006 (første gang inngått i 1947) mellom LO og DA et viktig utgangspunkt for informasjon og konsultasjon. Avtalen er bredt formulert 
og oppfordrer generelt til et høyt nivå av informasjon og konsultasjon. Begrepet outsourcing fremgår ikke direkte (i likhet med i Norge), men det er plikt til løpende å informere samarbeidsutvalget om virksomhedens økonomiske situasjon og fremtid, bedriftens bemanningsutsikter og "større ændringer og omlægninger bl.a. i anvendelsen af ny teknologi i produktion og administration" (Samarbejdsaftalen 2006, 8). Mer spesifikt forholder avtalen seg til hva virksomheten skal bestrebe og gjøre ved bortfall av arbeidsplasser, fortrinnsvis ved innføring av ny teknologi. Avtalen forholder seg altså ikke eksplisitt til outsourcing eller til virksomhetsovertakelser. Utover dette er et vesentlig element i reguleringen av arbeidstakernes rettigheter i forbindelse med virksomhetsovertakelser EU-direktiv 2001/23/EF 12. mars 2001. Dette direktivet er dels innarbeidet i samarbeidsaftalen, men også i 'Lov om lønmodtageres retsstilling ved virksomhedsovertagelse' hvorav det fremgår af $\S 2$, at:

\section{"Overdrages en virksomhed eller en del heraf, indtraeder erhververen umiddelbart $i$ de ret- tigheder og forpligtelser, der bestod på over- tagelsestidspunktet $i$ henhold til 1) kollektiv overenskomst og aftale, 2) bestemmelser om løn- og arbejdsforhold, der er fastsat eller godkendt af offentlig myndighed og 3) indi- viduel aftale om løn-og arbejdsforhold."}

Med andre ord: Både når det gjelder de generelle bestemmelser i overenskomsten og de kollektive og individuelle avtaler, som måtte være inngått individuelt, overtar den overtakende virksomhet som utgangspunkt de forpliktelser, som den foregående eier hadde overfor medarbeiderne.

Et annet forhold som har betydning for informasjon og konsultasjon er European Work Councils (EWC). I vår undersøkelse er $32 \%$ av selskaper i Norge og $38 \%$ av selskaper i Danmark dekket av EWC eller liknende strukturer. På grunn av at endringene som følge av EU direktiver angår et lite antall selskaper har vi ikke analysert disse nærmere.

\section{Data}

Det er to kriterier for at selskaper skal kunne velges ut til å delta i undersøkelsen: eierskap og størrelse (antall ansatte). Basert på disse kriteriene består utvalget vårt av to hovedgrupper av virksomheter (1) danskeog norskeide selskaper (i henholdsvis Danmark og Norge) som har minst 100 ansatte i andre land og på verdensbasis totalt minst 500 ansatte og (2) utenlandskeide selskaper med minst 100 ansatte i Danmark/Norge og totalt minst 500 ansatte på verdensbasis.

Responsraten for selskaper i Norge er henholdsvis $42 \%$ blant norskeide $(\mathrm{N}=36)$ og $21 \%$ blant utenlandskeide (N=47). Responsraten for selskaper i Danmark er henholdsvis $27 \%(\mathrm{~N}=31)$ for danskeide og $29 \%$ blant utenlandskeide (N=89). Frafallsanalyser viser at utvalget er representativt med hensyn til bransje for populasjonen av multinasjonale selskaper i Norge (Steen 2010). En tilsvarende sammenlikning er dessverre ikke mulig å gjøre for utvalget av selskaper i Danmark. Totalt består vårt utvalg av 203 selskaper. (På grunn av manglende verdier på enkelte variabler varierer $\mathrm{N}$ noe mellom tabellene). Det begrensete omfanget av utvalget skyldes først og fremst at det finnes få multinasjonale selskaper i Danmark og Norge. Som følge av det begrensete utvalget må vi operere med et fåtall forklaringsvariabler. Tabell 1 viser hvordan virksomhetene fordeler seg etter regimetype, størrelse og bransje.

Tabell 1 viser at blant de utenlandskeide selskapene i Norge $(\mathrm{N}=47)$ er $40 \%$ fra andre nordiske land ( $\mathrm{N}=19), 30 \%$ selskaper er fra andre land som kan karakteriseres som 
Tabell 1. \% virksomheter etter regime, størrelse og bransje

\begin{tabular}{|c|c|c|c|c|c|c|}
\hline & \multicolumn{2}{|c|}{ Norge } & \multicolumn{2}{|c|}{ Danmark } & \multirow[b]{2}{*}{ Alle } & \multirow[b]{3}{*}{$N$} \\
\hline & Norskeid & Utenlandskeid & Danskeid & Utenlandskeid & & \\
\hline & $\%$ & $\%$ & $\%$ & $\%$ & $\%$ & \\
\hline \multicolumn{7}{|l|}{ Regime } \\
\hline Nordisk CME & & 40 & & 26 & 31 & 42 \\
\hline Andre CME & & 30 & & 39 & 36 & 48 \\
\hline \multirow[t]{2}{*}{ LME } & & 30 & & 35 & 33 & 45 \\
\hline & & 100 & & 100 & 100 & 135 \\
\hline \multicolumn{7}{|l|}{ Størrelse } \\
\hline$<500$ ansatte & 31 & 47 & 26 & 70 & 51 & 101 \\
\hline 500 - 999 ansatte & 22 & 23 & 29 & 16 & 21 & 42 \\
\hline \multirow[t]{2}{*}{$>1000$ ansatte } & 47 & 30 & 45 & 14 & 29 & 57 \\
\hline & 100 & 100 & 100 & 100 & 100 & 200 \\
\hline \multicolumn{7}{|l|}{ Bransje } \\
\hline Industri & 56 & 53 & 60 & 46 & 52 & 94 \\
\hline \multirow[t]{2}{*}{ Service } & 44 & 47 & 40 & 54 & 48 & 100 \\
\hline & 100 & 100 & 100 & 100 & 100 & 194 \\
\hline N & 36 & 47 & 31 & 89 & & 203 \\
\hline
\end{tabular}

CME (hovedsakelig europeiske land) og 30 $\%$ fra land som regnes som LME (hvorav 8 selskaper er amerikanskeid). Blant de utenlandskeide selskapene i Danmark $(\mathrm{N}=89)$ er $26 \%(\mathrm{~N}=24)$ fra andre nordiske land, $39 \%$ fra andre CME-land og $35 \%$ fra land som regnes som LME (hvorav 12 selskaper er amerikanskeid).

Tabell 1 viser at $29 \%$ av selskapene har over 1000 ansatte, mens $51 \%$ har under 500 ansatte. Antall ansatte refererer til ansatte i henholdsvis Danmark og Norge (og ikke for det verdensomspennende selskapet). På grunn av enkelte avvik mellom informasjon fra registre og svarene i intervjuene finnes det et lite antall selskaper som har i underkant av 100 ansatte (dette gjelder 3 selskaper i Norge og 11 i Danmark). For øvrig er det en relativt sett høyere andel med selskaper i den minste gruppen i Danmark sammenliknet med Norge. Tabell 1 viser at fordelingen etter bransje hovedsakelig er den samme i Danmark og Norge.

For å kunne si noe om konsekvenser for arbeidstakere har vi har valgt ut spørsmål som dreier seg om kjernegruppen av ansatte. Dette er definert som the largest occupational group (LOG eller hovedgruppen). For måling av variabler, se note til tabeller.

\section{Funn}

Våre analyser er inndelt $\mathrm{i}$ to hoveddeler. Den første delen dreier seg om 'industrial 
relations' og belyser i hvilken grad multinasjonale selskaper i Norge og Danmark har ulike holdninger til fagforeninger og hvilke spørsmål som tas opp med fagforeninger. Den andre delen dreier seg om i hvilken grad det er forskjeller i HRM praksiser. Ut fra ny institusjonell teori antar vi at det kan være forskjeller mellom dansk- og norskeide selskaper sammenliknet med datterselskaper i disse arbeidsmarkedene. Videre antar vi på bakgrunn av det svakere oppsigelsesvernet i Danmark-ett av elementene i 'flexicurity' modellen-at spesielt spørsmål knyttet til bemanning kan vise et ulikt mønster i Norge og Danmark. I analysene skjelner vi mellom fire grupper av virksomheter: (1) Norskeide multinasjonale selskaper i Norge, (2) utenlandskeide selskaper i Norge (datterselskaper til multinasjonale), (3) danskeide multinasjonale selskaper i Danmark og (4) utenlandskeide selskaper i Danmark (datterselskaper til multinasjonale).

Tabell 2 viser utbredelsen av ledelsens anerkjennelse til fagforeninger. Tabellen viser at få av selskapene oppgir komplette fravær av anerkjennelse av fagforeninger. I tillegg viser tabellen at ca. halvparten (44-58\%) av selskapene anerkjenner fagforeninger $\mathrm{i}$ alle virksomhetene i henholdsvis Norge og Danmark. Med andre ord viser tabell 2 at samtlige grupper av selskaper er preget av høy grad av anerkjennelse av fagforeninger i de to arbeidsmarkedene.

I tabell 3 har vi konstruert en indeks basert på ledelsens holdning til fagforeninger og i hvilken grad fagforeningenes forhold til ledelsen karakteriseres med samarbeid. Basert på denne inndelingen kan virksomheter enten være karakterisert som at fagforeningen har en samarbeidstilnærming og at ledelsen er positiv til fagforeninger, en av delene, eller ingen av delene. Virksomheter som svarer at de har både positiv holdning til fagforeninger $o g$ at fagforeninger har en samarbeidstilnærming, er kategorisert som mest positiv. (Merk at når det gjelder holdning til samarbeid er dette ledelsens oppfatning av fagforeningens tilnærming).

Tabell 2. Anerkjennelse av fagforeninger. \% virksomheter

\begin{tabular}{|c|c|c|c|c|c|}
\hline & \multicolumn{2}{|c|}{ Norge } & \multicolumn{2}{|c|}{ Danmark } & \multirow[b]{2}{*}{ Total } \\
\hline & Norskeid & Utenlandskeid & Danskeid & Utenlandskeid & \\
\hline & $\%$ & $\%$ & $\%$ & $\%$ & $\%$ \\
\hline \multicolumn{6}{|l|}{ Fagforeninger anerkjennes i.. } \\
\hline $\begin{array}{l}\text { Ingen virksomheter i } \\
\text { Danmark/Norge }\end{array}$ & 16 & 11 & 13 & 21 & 16 \\
\hline Alle virksomheter & 53 & 49 & 58 & 44 & 49 \\
\hline De fleste virksomheter & 16 & 18 & 3 & 13 & 13 \\
\hline Noen virksomheter & 13 & 11 & 10 & 13 & 12 \\
\hline $\begin{array}{l}\text { Den eneste virksomheten } \\
\text { i Danmark/Norge }\end{array}$ & 3 & 11 & 16 & 9 & 10 \\
\hline Totalt & 100 & 100 & 100 & 100 & 100 \\
\hline
\end{tabular}

Note: Når du tenker på hovedgruppen i selskapet i Norge, er fagforeningen anerkjent som kollektiv representasjon ved......? Ingen, alle, de fleste, noen, den eneste virksomheten. Forskjellene mellom de fire gruppene av virksomheter er ikke signifikante. 
Tabell 3. Holdning til fagorganisering og samarbeid. \% virksomheter

\begin{tabular}{lrrrrrr} 
& \multicolumn{2}{c}{ Norge } & \multicolumn{2}{c}{ Danmark } \\
& & Norskeid & Utenlandskeid & Danskeid & Utenlandskeid \\
\hline Minst positiv (Ikke samarbeid eller positiv) & 1 & 7 & $\%$ & $\%$ & $\%$ \\
\hline & 2 & 25 & 49 & 21 & 26 \\
\hline Mest positiv (Samarbeid og positiv) & 3 & 68 & 26 & 50 & 29 \\
\hline Total & & 100 & 100 & 100 & 100 \\
\hline Forskjeller med kontroll for bransje & & & $* *$ & $*$ & + \\
\hline Forskjeller med kontroll for bransje og størrelse & & & & $*$ & $* *$ \\
\hline
\end{tabular}

${ }^{* *} \mathrm{p}<0.01,{ }^{*} \mathrm{p}<0.05,+\mathrm{p}<0.1$

Note: Indeks er basert på 2 spørsmål: Ledelsens policy ovenfor anerkjennelse av fagforeninger (for, imot, nøytral) og hvilken tilnærming fagforeningsrepresentantene har (en samarbeidende tilnærming, en konfliktbasert tilnærming, det avhenger av temaet). Signifikanstest er basert på ordinal logistisk regresjon med kontroll for bransje (industri og service) og med norskeide virksomheter som referanse.

For Norge viser tabell 3 at det er forskjeller mellom utenlandskeide og norskeide selskaper. Sammenliknet med norskeide selskaper (referanse), er utenlandskeide selskaper i Norge mindre tilbøyelig til å ha en samarbeidsprofil og være positive til fagforeninger. For eksempel havner $26 \%$ av utenlandskeide selskaper i Norge i kategorien som er minst positiv til fagforeninger, mens for norskeide virksomheter er det

Tabell 4. Holdning til fagorganisering og samarbeid etter type regimer. Utenlandskeide virksomheter. \%

\begin{tabular}{|c|c|c|c|c|c|c|c|c|c|}
\hline & & \multicolumn{4}{|c|}{ Norge } & \multicolumn{4}{|c|}{ Danmark } \\
\hline & & \multicolumn{3}{|c|}{ Regime } & \multicolumn{5}{|c|}{ Regime } \\
\hline & & $\begin{array}{l}\text { Nordisk } \\
\text { CME }\end{array}$ & $\begin{array}{l}\text { Andre } \\
\text { CME }\end{array}$ & LME & Alle & $\begin{array}{l}\text { Nordisk } \\
\text { CME }\end{array}$ & $\begin{array}{l}\text { Andre } \\
\text { CME }\end{array}$ & LME & Alle \\
\hline & & $\%$ & $\%$ & $\%$ & $\%$ & $\%$ & $\%$ & $\%$ & $\%$ \\
\hline \multirow[t]{2}{*}{$\begin{array}{l}\text { Minst positiv (Ikke sam- } \\
\text { arbeid eller positiv) }\end{array}$} & 1 & 25 & 31 & 20 & 26 & 33 & 23 & 22 & 26 \\
\hline & 2 & 38 & 46 & 70 & 49 & 19 & 27 & 39 & 29 \\
\hline \multirow[t]{2}{*}{$\begin{array}{l}\text { Mest positiv (Samarbeid } \\
\text { og positiv) }\end{array}$} & 3 & 38 & 23 & 10 & 26 & 48 & 50 & 39 & 46 \\
\hline & & 100 & 100 & 100 & 100 & 100 & 100 & 100 & 100 \\
\hline $\mathrm{N}$ & & \multicolumn{4}{|c|}{39} & \multicolumn{4}{|c|}{70} \\
\hline
\end{tabular}

Note: Nordiske CME inkluderer Danmark, Norge, Sverige, Finland og Island. LME inkluder USA, Storbritannia, Australia og delvis eierskap i disse landene. Andre CME inkluderer hovedsakelig ikke-nordiske europeiske land. Forskjellene er ikke signifikante. 
bare $7 \%$ i denne kategorien. Forskjellene mellom danskeide og utenlandskeide selskaper i Danmark er ikke signifikante. Det er videre en tendens til at danskeide virksomheter i mindre grad er positive til fagforeninger og har en mer negativ samarbeidstilnærming sammenliknet med norskeide. Mens $68 \%$ av norskeide virksomheter karakteriseres som mest positiv er andelen 50 $\%$ i danskeide virksomheter. Forskjellen er signifikant $(\mathrm{p}<0.05)$ etter kontroll for bransje og størrelse. Vi ser altså her, at det er forskjeller mellom norskeide og utenlanskeide virksomheter i Norge, mens det stort sett ikke er forskjeller mellom danskeide og utenlandskeide i Danmark. Dette antyder at opplevelsen av samarbeidet altså er vesentlig mer forskjellige i Norge enn i Danmark, når man sammenlikner utenlanskeide med 'hjemlige' virksomheter.

Tabell 4 viser holdninger til fagforeninger blant utenlandske selskaper brutt ned på 'regime of origin'. Vår antakelse er at utenlandske selskaper vil være mer negative og i mindre grad ha en samarbeidstilnærming sammenliknet med norsk- eller danskeide selskaper, og at dette spesielt ville være slående for selskaper fra LMEs. Det kan se ut som det er et slikt mønster-i hvert fall for selskaper i Norge-kun $10 \%$ av utenlandske selskaper fra LME regimer er i kategorien samarbeid og positiv til samarbeid, sammenliknet med $38 \%$ av nordiske (CME) selskaper. Forskjellene mellom de ulike gruppene er imidlertid ikke signifikante. Forskjellene er heller ikke signifikante når vi kontrollerer for bransje. For Danmarks vedkommende kan forskjellene synes betydelig mindre mellom regimer enn i Norge. Hvorvidt dette kan indikere at det danske systemet med et relativt svakt oppsigelsesvern passer LME-virksomheter godt, trenger vi et større utvalg av virksomheter for å kunne belyse nærmere.

Tabell 5 gir en oversikt over beskrivelse av hvilke strategier selskapene har i forhold til fagforeninger med hensyn til til følgende områder: organisering av arbeid,

Tabell 5. Beskrivelse av strategier i forhold til fagforeninger mht følgende områder: (Skala 1-5)

\begin{tabular}{lrcr|c} 
& \multicolumn{2}{c}{ Norge } & \multicolumn{2}{c}{ Danmark } \\
& Norskeid & Utenlandskeid & Danskeid & Utenlandskeid \\
\hline & Gj. Snitt & Gj. Snitt & Gj. Snitt & Gj. Snitt \\
\hline Organisering av arbeid & 3.00 & 2.90 & $2.50+$ & $2.30 *$ \\
\hline Under-leverandører og outsourcing & 2.28 & $2.74+$ & $1.64 *$ & 1.75 \\
\hline Variabel lønn & 2.96 & 3.03 & 3.25 & 3.00 \\
\hline Opplæring & 3.13 & 2.74 & 3.13 & 2.97 \\
\hline Ansatte involvering & 3.78 & $2.86 * *$ & $3.00 *$ & $2.95 *$ \\
\hline $\mathrm{N}$ & 26 & 39 & 24 & 63 \\
\hline
\end{tabular}

${ }^{* *} \mathrm{p}<0.01,{ }^{*} \mathrm{p}<0.05,+\mathrm{p}<0.1$

Note: Hva beskriver best virksomhetens policy for samarbeid med fagforeninger på områder som gjelder hovedgruppen? Ledelsen bestemmer selv=1, Ledelsen konsulterer fagforeningsrepresentanter $=3$, Ledelse bestemmer i samråd med fagforeningsrepresentanter $=5$. Forskjellene er testet ved lineær regresjon med kontroll for bransje og størrelse. Forskjellene mellom utenlandskeide og danskeide/norskeide i hhv Danmark og Norge er ikke signifikante. 
underleverandører og outsourcing, variabel lønn, opplæring og generelt om ansatte involvering. Som påpekt gir det relativt svake oppsigelsesvernet i Danmark arbeidsgivere større grad av bemanningsfleksibilitet. Vi ønsker å belyse om dette også preger i hvilke spørsmål arbeidsgivere konsulterer fagforeningene. Tabell 5 viser at virksomheter i Danmark (både danskeide og utenlandske) er mindre tilbøyelig til å inkludere fagforeningsrepresentanter $\mathrm{i}$ beslutninger når det gjelder tre av temaområdene: organisering av arbeid, under-leverandører og outsourcing, og ansattes involvering. Langs disse dimensjonene har danskeide selskaper lavere score enn norskeide selskaper. Til tross for at samhandling mellom arbeidsgivereog takere er regulert i lovverk og tariff- eller samarbeidsavtaler både i Norge og Danmark finner vi altså en forskjell her. Tabell 5 viser gjennomsnittet på en skala fra 1 (= ledelsen bestemmer selv) til 5 (= ledelse bestemmer i samråd med fagforeningsrepresentanter). På grunn av få enheter i hver kategori er analysene også sjekket ved en tre-deling av skalaen. Denne analysen viser hovedsakelig det samme som funn presentert i tabell 5 .

Vi har sett at det er visse forskjeller i samarbeid og holdning til fagforeninger mel- lom selskaper i Norge og Danmark. Vi vil nå se i hvilken grad det er ulikheter i spesifikke HRM praksiser. Tabell 6 viser i hvilken grad det er forskjeller i HRM praksiser mellom danske og norske multinasjonale selskaper i henholdsvis Danmark og Norge, og i hvilken grad det er forskjeller mellom 'hjemmeeide' selskaper og utenlandske selskaper i henholdsvis Danmark og Norge.

Tabell 6 viser en oversikt over forekomst av HRM praksiser knyttet til involvering og kommunikasjon mellom ledelse og ansatte. Alle områdene er knyttet til hovedgruppen av ansatte. Vi har valgt ut praksiser som har betydning for jobbkvalitet til arbeidstakere. Dette er også praksiser hvor vi antar at det kan være forskjeller mellom spesielt norskog danskeide selskaper og utenlandskeide selskaper.

Tabell 6 viser for det første, at bruken av arbeidsgrupper og formelle team er meget utbredt i både Norge og Danmark. Den skandinaviske tradisjonen synes at slå igjennom her. For det andre viser tabell 6 at det er relativt små forskjeller mellom alle de fire gruppene av virksomheter. Et unntak er bruk av arbeidsgrupper som er minst utbredt i danskeide virksomheter. Dette gjelder også etter kontroll for bransje og størrelse. Imid-

Tabell 6. Forekomst av HRM praksiser for involvering. \% virksomheter

\begin{tabular}{lccccc} 
& \multicolumn{2}{c|}{ Norge } & \multicolumn{2}{c}{ Danmark } \\
& Norskeid & Utenlandskeid & Danskeid & Utenlandskeid \\
\hline & $\%$ & $\%$ & $\%$ & $\%$ \\
\hline Formelle team & 81 & 74 & 76 & 70 \\
\hline Arbeidsgrupper & 91 & 81 & $69{ }^{*}(+)$ & 79 \\
\hline $\begin{array}{l}\text { Regelmessig bruk av team/task forces for ansatte } \\
\text { (ikke ledere) }\end{array}$ & 92 & 92 & 88 & 86 \\
\hline
\end{tabular}

${ }^{* *} \mathrm{p}<0.01,{ }^{*} \mathrm{p}<0.05,+\mathrm{p}<0.1$

Note: Bruker dere noen av de følgende tiltak i forhold til hovedgruppen i selskapet i Norge/Danmark? (ja=1, nei=0). Signifikanstester er beregnet ved logistisk regresjon med kontroll for bransje og norskeide selskaper som referanse. Signifikanstester i () refererer til forskjeller mellom danskeide og utenlandske selskaper i Danmark. 
Tabell 7. Forekomst av praksiser for kommunikasjon og type informasjon. \% virksomheter

\begin{tabular}{lcccc} 
& \multicolumn{2}{c}{ Norge } & \multicolumn{2}{c}{ Danmark } \\
& Norskeid & Utenlandskeid & Danskeid & Utenlandskeid \\
\hline & $\%$ & $\%$ & $\%$ & $\%$ \\
\hline Praksiser for kommunikasjon & & & & \\
\hline $\begin{array}{l}\text { Møter mellom senior ledere og hele } \\
\text { arbeidsstokken }\end{array}$ & 81 & 80 & 79 & 81 \\
\hline Møter mellom linjeleder og ansatte & 87 & 93 & 90 & 92 \\
\hline Type informasjon & & & 97 & 93 \\
\hline Finansiell stilling & 97 & 93 & 43 & 48 \\
\hline Investeringsplaner & 57 & 40 & $37+\left(^{*}\right)$ & 55 \\
\hline Bemanningsplaner & 57 & 61 & 31 & 88 \\
\hline $\mathrm{N}$ & 31 & 47 & & \\
\hline
\end{tabular}

${ }^{* *} \mathrm{p}<0.01,{ }^{*} \mathrm{p}<0.05,+\mathrm{p}<0.1$

Note: Hvilke av de følgende mekanismer eller tiltak vil du vanligvis bruke for å kommunisere med hovedgruppen? ( $\mathrm{ja}=1$, nei=0) Hvilke av følgende type informasjon blir regelmessig lagt frem for hovedgruppen i selskapet? $(j a=1$, nei=0). Signifikanstester er beregnet ved logistisk regresjon med kontroll for bransje og størrelse og norskeide selskaper som referanse. Signifikanstester i () refererer til forskjeller mellom danskeide og utenlandske selskaper i Danmark.

lertid kan det tenkes at våre kontrollgrupper er for grove til tilstrekkelig å kunne belyse dette spørsmålet. Arbeidsgrupper er for øvrig, ikke overraskende, mer utbredt i industrisektoren enn servicesektoren.

Tabell 7 viser at praksiser for kommunikasjon er utbredt. Når det gjelder forskjeller mellom 'hjemmeeide' og utenlandske virksomheter finner vi kun signifikante forskjeller i Danmark ved ett tilfelle. Danskeide virksomheter er i mindre grad tilbøyelig til å gi informasjon om bemanningsplaner sammenliknet med utenlandskeide virksomheter i Danmark. Etter kontroll for størrelse er denne forskjellen signifikant på 10-\% nivå. Til slutt finner vi i en videre analyse at en del av forholdene rundt kommunikasjon, møter mellom seniorleder og hele arbeidsstokken, og informasjon om investeringsplaner, forekommer oftere i industri- enn i servicesektoren.

\section{Konklusjon}

I denne artikkelen har vi studert arbeidslivsregimer blant multinasjonale selskaper i Norge og Danmark. Artikkelen gir et oversiktsbilde av holdninger til fagforeninger, samarbeid og HRM praksiser $i$ en av de mest omfattende undersøkelsene av HRM praksiser i multinasjonale selskaper i Danmark og Norge. På bakgrunn av 'flexicurity' modellen, spesielt med tanke på det relativt svake oppsigelsesvernet i Danmark, har vi belyst hvorvidt forskjeller i institusjonelle trekk mellom Danmark og Norge kommer til uttrykk i HRM regimer blant disse selskapene. I tillegg har vi sett i hvilken grad det er forskjeller mellom utenlandskeide og norsk- og danskeide selskaper.

Vi rapporterer tre hovedfunn:

For det første finner vi at alle grupper av datterselskaper til utenlandske multinasjonaleselskaper er preget av høy grad av an- 
erkjennelse av fagforeninger i de to arbeidsmarkedene. Vi observerer en tendens til at utenlandske multinasjonale selskaper er mindre positive til fagforeninger sammenliknet med 'hjemmeeide'. Dette er i tråd med tidligere forskning vi har rapportert som med utgangspunkt i ny-institusjonell teori fant hyrbide tilpasninger blant multinasjonale datterselskaper i Norden (Gooderham et al. 2006). Forskjellen er imidlertid kun signifikant i Norge. Vi antar at dette dels kan forklares med den særegne norske konteksten. Sammenliknet med de fleste land er det større tradisjon for samarbeid i Norge. Denne effekten kan være varig eller den kan endres over tid ved at utenlandskeide virksomheter 'lærer spillereglene' som gjelder i Norge. Denne antakelsen om Norge som en særegen kontekst støttes av at vi ikke finner forskjeller på tvers av opphavsregimene til datterselskapene.

For det andre finner vi at selskaper i Danmark i noe mindre grad enn selskaper i Norge er positive til fagforeninger, og vi ser forskjeller med hensyn til hvilke spørsmål ledelsen konsulterer fagforeninger. Vi finner at forskjellene spesielt kommer til uttrykk ved at selskaper i Danmark i lavere grad konsulterer fagforeninger i spørsmål som har med underleverandører samt outsourcing, organisering av arbeid, og ansattes involvering sammenliknet med sine norske motparter. Presis når det gjelder bemanningsplaner ser vi, at det er et område, hvor danskeide virksomheter i Danmark i mindre grad informerer og konsulterer medarbeidersiden, sammenliknet med norskeide virksomheter i Norge.

Spørsmålet er, i hvilken grad 'flexicurity' modellen kan forklare denne forskjellen. Det danske systemet gir en vesentlig høyere bemanningsfleksibilitet enn i det norske systemet, hvor oppsigelsesvernet er strengere. Samtidig må vi påpeke at krav til opplysning og kommunikasjon vedrø- rende endringer i organisering både i Norge og Danmark er regulert i lovverk og tariff-/ samarbeidsavtaler. En forklaring på, at det i en dansk sammenheng ikke er stor forskjell på utenlandskeide og danskeide selskaper i holdningen til fagforeninger, er sannsynligvis, at virksomhetene generelt opplever reguleringen av arbeidsvilkår og i særdeleshet ansettelses- og oppsigelsesregler som relativt liberale. Som påpekt er reguleringen i en dansk sammenheng i vid utstrekning basert på overenskomster, som partene selv avtaler. Overenskomster med liberale ansettelses- og oppsigelsesregler stiller således fagforeningene i et positivt lys, sett fra virksomhetenes synspunkt.

Det kan imidlertid stadig undre, at danske virksomheder generelt konsulterer fagforeningsrepresentanter mindre, når det gjelder organiseringen av arbeidet, de ansattes involvering og bruk av underleverandører og outsourcing. Samarbeidsavtalen foreskriver klart, at slike forhold skal diskuteres i samarbeidsutvalget, men ikke desto mindre synes en del virksomheter ikke å leve opp til dette-i hvert fall ikke så stor en andel, som det ses i Norge. Enkelte elementer $\mathrm{i}$ det norske systemet tyder på en noe mer tvingende lovgivning, for eksempel er det et lovmessig krav at bruk av midlertidig ansatte skal drøftes med tillitsvalgte i Norge.

En annen - og utdypende - forklaring kan også ligge i at tillitsrepresentanten i en dansk sammenheng er valgt blant medlemmer av en fagforening-men bestemt ikke alltid oppfattes av ledelsen som først og fremst en fagforeningsrepresentant. Kun $14 \%$ av ledere ser tillitsrepresentanten som en talsperson for faglige synspunkter, mens tre av fem ser tillitsrepresentanten som mediator på virksomheten (Larsen et al. 2010). Dermed kan svaret på spørsmålet om, hvorvidt fagforeningen involveres i en rekke forhold være tvetydig i en dansk sammenheng. 
For det tredje er det i hovedsak likheter i forekomst av HRM praksiser blant multinasjonale selskaper i Norge og Danmarkdet gjelder både norsk/danskeide og utenlandskeide (datterselskaper). En forklaring på de store likhetene er at vår undersøkelse omfatter relativt store virksomheter hvor arrangementer som team, arbeidsgrupper er utbredt, uavhengig av opprinnelsesland. Vi finner at stort sett alle HRM praksisene forekommer ofte - gjennomgående svarer mellom 75 og $90 \%$ av virksomhetene at de bruker praksiser som formelle team, arbeidsgrupper og regelmessig bruk av task forces som fremmer medbestemmelse og involvering. For øvrig er dette i tråd med at arbeidstakere i Skandinaviske land har stor grad av medbestemmelse og autonomi (Gallie 2003; Esser \& Olsen 2011). Når det gjelder praksiser for kommunikasjon har over $80 \%$ av selskapene regelmessige møter mellom ledere og ansatte. Informasjon om finansielle planer framstår hyppigere enn planer om investeringer og bemanning.

Når det gjelder konsekvenser for arbeidstakere viser våre analyser at det er store likhetstrekk mellom HRM praksiser i multinasjonale selskaper i Norge og Danmark. Dette kan tyde på at utenlandskeide selskaper tilpasser seg arbeidsmarkedene de kommer til. For å teste dette videre ville det være ønskelig med en bredere sammenlikning av HRM praksiser blant utenlandskeide selskaper også i andre land med andre institusjonelle forhold.

Den danske modellen med høy fleksibilitet for arbeidsgiver med hensyn til bemanning, sjenerøse forsikringsordninger og en aktiv arbeidsmarkedspolitikk har vist at mobilitet fra inaktivitet til arbeid er relativt høy i Danmark i forhold til andre nordiske land (TemaNord 2010). Til tross for at jobbsikkerhet i en gitt jobb er lav i Danmark, er understøttelsen sjenerøs og muligheten for raskt å få en annen jobb stor, og dermed også sikkerheten for inntekt god (Anderson $\&$ Pontusson 2007). Dette viser hvordan kombinasjonen av elementer fra velferdssystemer og arbeidsmarkedsreguleringer har konsekvenser for den enkelte arbeidstaker. Vi har i denne artikkelen sett på noen mulige indirekte konsekvenser av reguleringer knyttet til bemanning og ansettelser for multinasjonale selskaper. Når arbeidsgivere har større frihet i forhold til bemanningsløsninger kan dette ha konsekvenser for hvilke spørsmål som tas opp med fagforeninger og tillitsvalgte. Enkelte av våre funn kan således tyde på at reguleringer av ansettelsesforhold, med det relativt svake oppsigelsesvernet i Danmark, har-eller er i ferd med-å endre trekk ved relasjoner mellom arbeidstakere og -givere i Danmark. Multinasjonale selskaper i Danmark er for så vidt ganske positive til fagforeninger, men på samme tid mindre tilbøyelig til å involvere fagforeninger i enkelte spørsmål. En tese kan være, at den relativt (sammenlignet med Norge) liberale reguleringen av informasjons- og konsultasjonsplikt i forbindelse med restruktureringer utnyttes av multinasjonale selskaper til å involvere medarbeidersiden mindre. Hvis dette er tilfellet, kan der være behov for en revidering av den danske samarbeidsmodellen, slik at den også evner å møte de utfordringer, som utenlandsk eierskap utgjør. Enkelte av våre funn tyder på at de multinasjonale selskaper på dette område ikke tilpasser seg danske tradisjoner for informasjon i samarbeidsutvalg, og kanskje mest overraskende er det, at de danskeide multinasjonale virksomheter altså tar en mindre kommuniserende holdning.

Våre analyser er ikke uten svakheter. En svakhet er at forekomst av HRM praksiser består i relativt grove mål. En annen er utvalgets størrelse. Som vi har påpekt skyldes dette først og fremst at det er relativt få slike selskaper i Norge og Danmark. Dette hindrer oss i å studere undergrup- 
per av selskaper i særlig grad og begrenser antallet bakgrunnsvariabler. Ved et større antall virksomheter ville vi for eksempel kunne belyse i hvilken grad det er forskjeller på bakgrunn av opprinnelsesland. På den annen side er det viktig å understreke at vårt utvalg rommer en betydelig andel av de danske og norske multinasjonale selskapene og likedan utenlandske multinasjonale selskaper med virksomheter i de to landene. Som sådan vil vi gjenta at dette er

\section{RefERANSER}

Amable, B. (2003): The Diversity of Modern Capitalism, Oxford, Oxford University Press.

Anderson, C. J. \& J. Pontusson (2007): Workers, worries and welfare states: Social protection and job insecurity in 15 OECD countries, i European Journal of Political Research, 46, 2, 211-235.

Arbeidsmiljøloven (AML), LOV 2005-06-17 nr 62: Lov om arbeidsmiljø, arbeidstid og stillingsvern mv.

Campbell, J.L., J.A. Hall \& O.K. Pedersen (red.) (2006): National Identities and The Varities of Capitalism; The Danish Experience, København, DJØF.

DiMaggio, P. J. \& W. W. Powell (1983): The iron cage revisited: institutional isomorphism and collective rationality in organizational fields, i American Sociological Review, 48, 147-160.

Esser, I. \& K.M. Olsen (2011): Perceived Job Quality: Autonomy and Job Security within a Multilevel Framework, i European Sociological Review (forthcoming).

Gallie, D. (2003): The quality of working life: Is Scandinavia different? i European Sociological Review, 19, 1, 61-79.

Gooderham, P. N., O. Nordhaug \& K. Ringdal (1999): Institutional determinants of organizational practices: human resource management in European firms, i Administrative Science Quarterly, 44, 3, 507-531.

Gooderham, P. N., O. Nordhaug \& K. Ringdal et unikt datamateriale. En tredje svakhet er at vi ikke kan si hvor mye av forskjellene som skyldes at de dansk- og norskeide selskapene er hovedkontorer, mens de utenlandskeide er datterselskaper. De er altså organisatoriske enheter på ulike nivåer. På den annen side vil vi fremheve at samtlige av de enhetene som datasettet vårt rommer er ytterst synlige selskaper. Dermed avspeiler de innvirkningen av de institusjonelle omgivelsene på en spesielt tydelig måte.

(2006): National Embeddedness and HRM Practices in US Subsidiaries in Europe and Australia, i Human Relations, 59, 11, 14911513.

Gooderham, P. N. \& O. Nordhaug (2011): One European model of HRM? Cranet empirical contributions, Human Resource Management Review, 21, 27-36.

Hall, P. A. \& D. W. Gingerich (2004): Varieties of capitalism and institutional complementarities in the macroeconomy, MPIfG Discussion paper 04/5, Berlin, Max Planck Institut für Gesellschaftsforschung.

Hall, P. \& D. Soskice (red.) (2001): Varieties of Capitalism: The Institutional Basis of Competitive Advantage, Oxford, Oxford University Press.

Hollingsworth, J. R. (2006): Advancing our understanding of capitalism with Niels Bohr's thinking about complementarity, i P. James $\&$ G. Wood (red.): Institutions and Working Life, Oxford, Oxford University Press.

Jusstorget (2011): www.jusstorget.no. Lastet ned 14. april 2011.

Katz, H.C. \& O. Darbishire (2000): Converging Divergences. Worldwide Changes in Employment Systems, Ithaca, Cornell University Press.

Keller, B.K. \& A. Kirsch (2011): Employment relations In Germany, i G.J. Bamber, R.D. Lansbury \& N. Wailes (red.): International and Comparative Employment Relations: Globalisation and Change, Los Angeles, Sage. 
Larsen, T.P., S. E. Navrbjerg \& M. M. Johansen (2010): Tillidsreproesentanten og arbejdspladsen, København, LO.

Løken, E. (2009): De nordiske modellene etter 2000 - bakgrunn og fellestrekk, Oslo, Fafonotat 2009, 08.

Madsen, P. K. (2003): "Flexicurity" through labour market policies and institutions in Denmark, i P. Auer \& S. Cazes (red.): Employment stability in an age of flexibility, Geneva, International Labour Office, 59-105.

Madsen, J.S., J. Due \& S.K. Andersen (2011): Employment relations in Denmark, i G.J. Bamber, R.D. Lansbury \& N. Wailes (red.): International og Comparative Employment Relations: Globalisation and Change, Los Angeles, Sage.

Meyer, J. W. \& B. Rowan (1983): Institutionalized organizations: formal structure as myth and ceremony, i W. Meyer, B. Rowan \& T. E. Deal (red.): Organizational Environments Ritual and Rationality, Beverly Hills, Sage Publications, 21-44.

OECD (2008): OECD Indicators of Employment Protection, www.oecd.org. Lastet ned 14. Juni 2011.

Pfeffer, J. \& J. N. Baron (1988): Taking the Workers Back Out - Recent Trends in the Structuring of Employment, i Research in Organizational Behavior, 10, 257-303.
Samarbejdsnævnet (2006): Samarbejdsaftalen 2006. Indgået mellem Dansk Arbejdsgiverforening og Landsorganisationen i Danmark. www.samarbejdsnaevnet.dk/ /media/ LO\%20Samarbejdsnaevnet/udgivelser/Samarbejdsaftelen_2006\%20pdf.ashx

Rogaczewska, A. P. et al. (2004): Denmark and Norway: siblings or cousins? i C. Brewster, W. Mayrhofer \& M. Morley (red.): Human Resource Management in Europe. Evidence of Convergence? Oxford, Elsevier.

Scott, W. R. (2001): Institutions and organizations, Second edition, Thousand Oaks, Sage.

Steen, C. R. (2010): Survey av HR praksiser i multinasjonale selskaper i Norge. Presentasjon av første resultater, Solstrand.

Tolbert, P. S. \& L. G. Zucker (1996): The institutionalization of institutional theory, i S. R. Clegg, C. Hardy \& W. A. Nord (red.): Handbook of organization studies, London, Sage.

TemaNord (2010): Labour Market Mobility in Nordic Welfare States, Copenhagen, Nordic Council of Ministers.

Wailes, N., G. J. Bamber \& R. D. Lansbury (2011): International and comparative employment relations: An introduction, i G.J. Bamber, R.D. Lansbury \& N. Wailes (red.): International and Comparative Employment Relations: Globalisation and Change, Los Angeles, Sage.

Paul Gooderham, professor i internasjonal ledelse på Norges Handelshøyskole (NHH) e-mail: Paul.Gooderham@nhh.no

Steen E. Navrbjerg, lektor på Forskningscenter for Arbejdsmarkeds- og Organisationsstudier (FAOS), Sociologisk Institut, Københavns Universitet e-mail: sen@faos.dk

Karen M. Olsen, professor på Institutt for Strategi og Ledelse, Norges Handelshøyskole $(\mathrm{NHH})$

e-mail: Karen.Olsen@nhh.no

Christina R. Steen, ph.d.-stipendiat på Institutt for Strategi og Ledelse, Norges Handelshøyskole (NHH)

e-mail: Christina.Steen@nhh.no 